\title{
FANDING OF PARASITIC NEMATODES OF FISHES PRESENT IN THE MARKET
}

\author{
Miroslav Cirković 1 , Nikolina Novakov ${ }^{2}$, Jelena Petrović ${ }^{1}$, \\ Dragana Ljubojevićc', Jelena Apić ${ }^{1}$, Jelena Babić1, Vlado Teodorović ${ }^{3}$ \\ ${ }^{1}$ Scientific Veterinary Institute Novi Sad, Novi Sad, Serbia \\ ${ }^{2}$ Faculty of Agriculture, Novi Sad, Serbia \\ ${ }^{3}$ Faculty of Veterinary Medicine, Belgrade, Serbia
}

\section{Abstract}

When placing the fish and fish products on the trade it is necessary to pay attention to the presence of zoonotic parasites that can lead to infection of people especially if the fish is consumed raw or undercooked. Epidemiologically the most important are helminths from the group of Nematoda. The most important are Anisaxis spp. and Eustrongylides excisus. Anisakiasis is a serious zoonotic disease with a dramatic increase in prevalence throughout the world in the last two decades. The larvae are found in marine fish species most frequently in sardines, herring and mackerel. Eustrongylidosis is a disease that occurs primarily in freshwater fish species: catfish, zander and pike, a cause is a parasite of the genus Eustrongylides of which the most important species is Eustrongylides excisus. In this paper, the nematodes that occur in fish that are present in the market in the Republic of Serbia are present. Investigations of Anisaxis spp. were carried out at the Institute of Veterinary Medicine Novi Sad in the period of 2000-2013. Total of 2414 samples of imported marine fish was inspected. In 25 (1.29\% ) samples of herrings (Clupea harengus) and mackerels (Scomber scombrus) was identified Anisakis spp. Investigations of Eustrongylides spp . were carried out in the period 2010-2013 at the Danube- Tisa - Danube Canal. Samples were collected from zander (Sander lucioperca) and European catfish (Siluris glanis) in which the presence of nematodes was found in the abdominal cavity, muscles, the lumen of the stomach and gastric wall where the parasites were encapsulated. Individuals of zander were examined during the 2013 at the Veterinary Institute Novi Sad, where the presence of larvae Eustrongylides spp.u muscle was detected. In order to avoid infecting people with parasites of fish it is necessary to carry out continuous control and monitoring. Fresh

${ }^{1^{*}}$ E-mail: dragana@niv.ns.ac.rs 
fishes and traditional fish products must be inspected for the presence of parasites before they find on the trade. Continuous education is a key factor in combating zoonotic diseases. Avoid consumption of raw or poorly cooked fish is still the best preventive procedure.

Key words: zoonotic nematodes, Anisakis spp., Eustrongylides excisus, fish, market

\title{
NALAŽENJE PARAZITSKIH NEMATODA KOD RIBA NA TRŽIŠTU
}

\author{
Miroslav Ćirković 1, Nikolina Novakov2, Jelena Petrović1, Dragana \\ Ljubojević1, Jelena Apić1, Jelena Babić1, Vlado Teodorović 3 \\ 1 Naučni institut za veterinarstvo Novi Sad, Novi Sad, Srbija \\ 2Poljoprivredni fakultet, Novi Sad, Srbija \\ 3Fakultet veterinarske medicine, Beograd, Srbija
}

\section{Kratak sadržaj}

Prilikom stavljanja u promet i pregleda ribljeg mesa i proizvoda od ribe treba obratiti pažnju na prisustvo zoonotskih parazita koji mogu dovesti do inficiranja ljudi naročito ako se riba konzumira sirova ili termički nedovoljno obrađena. Sa epidemiološkog aspekta najveći značaj imaju helminti iz grupe Nematoda. Najznačajnije su Anisaxis spp. i Eustrongylides excisus. Anisakijaza je ozbiljno zoonotsko obolenje sa dramatičnim porastom prevalence širom sveta u poslednje dve decenije. Larve se mogu naći kod morskih vrsta riba najčešće kod sardine, haringe i skuše. Eustrongilidoza je obolenje koje se javlja kod slatkovodnih riba prvenstveno grabljivica: soma, smuda i štuke, a izazivaju je paraziti iz roda Eustrongylides od kojih je najznačajnija vrsta Eustrongylides excisus. U ovom radu prikazane su nematode koje se javljaju kod riba koje su prisutne na tržištu u Republici Srbiji. Istraživanja prisustva Anisaxis spp. su sprovedena na Naučnom institutu za veterinarstvo Novi Sad u periodu 2000-2013. Ukupno je pregledano 2414 uzoraka riba iz uvoza od čega je u 25 (1.29\%) utvrđen Anisakis spp., kod haringe (Clupea harengus) i skuše (Scomber scombrus). Istraživanja prisustva Eustrongylides spp. su sprovedena u periodu od 2010-2013 godine na kanalu Dunav-Tisa-Dunav. Prikupljeni su uzorci konzumnog smuda (Sander lucioperca) i soma (Siluris glanis) kod kojih je utvrđeno prisustvo nematoda u abdomenu, muskulaturi, lumenu želuca i želudačnom zidu gde su paraziti bili inkapsulirani. Jedinke smuda pregledane se tokom 2013. godine i 
na Naučnom Institutu za veterinarstvo Novi Sad gde je utvrđeno prisustvo larvi Eustrongylides spp.u muskulaturi. Kako ne bi došlo do zaražavanja ljudi zoonotskim parazitima riba neophodno je sprovoditi stalnu kontrolu i monitoring. Sveže meso ribe i tradicionalni riblji proizvodi pre nego što se nađu u prometu moraju biti pregledani na prisustvo parazita. Kontinuirana edukacija je ključni faktor u borbi sa zoonozama a izbegavanje konzumiranja sirovog ili termički slabo obrađenog ribljeg mesa i dalje najbolja preventivna procedura.

Ključne reči: zoonotske nematode, Anisakis spp., Eustrongylides excisus, ribe, tržište

\section{INTRODUCTION}

Zoonotic nematodes infect freshwater and marine fish species. Pathology normally occurs within the intestines but can affect all organs. Nematodes can infect fish as adults but larval stages of nematodes infecting piscivorous birds, mammals or reptiles, or less frequently predatory fish, can also infect fish species (Roberts and Janovy, 2000). Some nematodes are zoonotic. Among these parasite Anisakis spp. has the highest medical importance because of the severe allergic reactions and gastrointestinal symptoms it causes in humans after eating or handling infected fish or crustaceans (Lima dos Santos and Howgate, 2011). These symptoms are especially prevalent in countries where it is common to eat raw or undercooked fish. Anisakiasis a serious zoonotic disease with a dramatic increase in prevalence throughout the world in the last two decades. People who are usually accidental hosts infected when ingest the third larval stage of the parasite that can be found in the internal organs and muscles of a large number of marine and anadromous fish (sardines, herring, salmon, tuna, mackerel, etc.) (Bullini, 1997; Oliva, 1999). Definitive host of Anisaxis species are marine mammals commonly dolphins and whales in which intestines are adult forms of the parasite. The first intermediate hosts are marine crustaceans and second intermediate hosts are cephalopods and fishes. Anisakis simplex is present in Atlantic, Pacific, Mediterranean Sea, Norwegian Sea and Barents Sea. The highest prevalence of anisakiasis is found in nort Asia and western Europe (Netherlads, Germany, France and Spain) (Chai et al., 2005). In Serbia Anisakis can be present in imported marin fish.

The most significant freshwater fish zoonotic nemotods which occurs in Serbia are Eustrongylides species (Ljubojević et al., 2012: Novakov et al., 2013). Thay have complex life cycles involving a definitive host and two intermediate hosts. Definitive hosts include aquatic birds mostly from order Ciconiiformes family Ardeidae, Anseriformes, Gaviiformes and Pelecaniformes (Spalding 
and Forrester, 1993; Measures 1988). First intermediate hosts for Eustrongylides spp. are aquatic oligochaetes (Spalding et al., 1993). Second intermediate hosts are planktivorous and benthivorous fishes that could pass the infection on to fishes (paratenic hosts) and finally on to fish-eating birds (Moravec, 1994). Such exposure is usually common in larger fish species, like channel catfish - Ictalurus punctatus or pike-perch - Sander lucioperca, which, as predators, become infected with Eustrongylides spp. nematodes. In fish, these parasites are conspicuous as long, red, coiled individuals located in the body cavity or embedded in the muscle (Mitchum 1995, Overstreet 2003).

In humans who have consumed raw or undercooked fish, Eustrongylides spp. have produced gastritis and intestinal perforation (Deardorff and Overstreet 1991; Cole 1999). Guerin et al., (1982) were the first to report a natural (accidental) human infection with Eustrongylides spp.

The goal of this paper is to distinguish the presence of Anisakis spp. and Eustrongylides spp. nematodes in marine and freshwater fish species that are present in the market and inland waters of Serbia and to indicate the need for adequate preparation of fish meat.

\section{MATERIAL AND METHODS}

Investigations of Anisaxis spp. were carried out at the Institute of Veterinary Medicine Novi Sad in the period of 2000-2013. Total of 2414 samples of imported marine fish was inspected. Each fish was eviscerated and carefully examined. In same cases muscles of fish were checked by method of artificial digestion.

Diagnostics and investigations of Eustrongylides spp. larvae were conducted from 2010-2013. Fifty two fish samples of European catfish (Siluris glanis) weighing 250-450 $\mathrm{g}$ and twenty one samples of zander (Sander lucioperca) were collected from different locations on Danube-Tisa-Danube Canal. Fishes were parasitologically examined through cutting the body and the abdominal part, digestive tract and other ventral organs. Samplaes of zander was also examined at the Institute of Veterinary Medicine Novi Sad during 2013. Collected nematodes were were fixed in $70 \%$ ethanol for $24 \mathrm{~h}$ and cleared in lactic acid for morphological observation. Relative parametars were measured and identification was performed using Bauer (1987), Moravec (1994) and Anderson (2000) keys. 


\section{RESULTS AND DISCUSSION}

Anisakis spp was first isolated in the laboratory of Veterinary Institute of Novi Sad in 2003. On a total of 2414 samples of imported marine fishes, in 25 (1.29\%) was found Anisakis spp. Presence of Anisakis spp. in samples of imported fish from 2000-2013 are shown in table 1 and chart 1. Coiled nematodes were present in herring (Clupea harengus) and mackerel (Scomber scombrus) (Fig. 1). Common to all positive samples is the presence of the viscera, because fishes were not eviscerated after fishing. Number of parasites ranged from 2-3 to 52 nematodes per fish. In two samples $(0.08 \%)$ the presence of larvae in fish muscles was performed by the method of artificial digestion.

Table 1. Presence of Anisakis spp. in samples of imported fish.

\begin{tabular}{|c|c|c|c|}
\hline Years & $\begin{array}{c}\text { Number of } \\
\text { inspected fish }\end{array}$ & $\begin{array}{c}\text { Number of } \\
\text { positive fish }\end{array}$ & \% of positive fish \\
\hline 2000 & 12 & 0 & 0 \\
\hline 2001 & 12 & 0 & 0 \\
\hline 2002 & 17 & 0 & 0 \\
\hline 2003 & 66 & 3 & 4.54 \\
\hline 2004 & 268 & 3 & 1.2 \\
\hline 2005 & 239 & 4 & 1.67 \\
\hline 2006 & 212 & 1 & 0.41 \\
\hline 2007 & 151 & 3 & 2 \\
\hline 2008 & 177 & 3 & 1.69 \\
\hline 2009 & 394 & 5 & 0.45 \\
\hline 2010 & 440 & 2 & 0 \\
\hline 2011 & 240 & 0 & 0 \\
\hline 2012 & 148 & 0 & 2.63 \\
\hline 2013 & 38 & 1 & \\
\hline
\end{tabular}


Archives of Veterinary Medicine, Vol. 6, No. 2, 3-13, 2013.

Cirković M. i dr: Fanding of parasitic ...

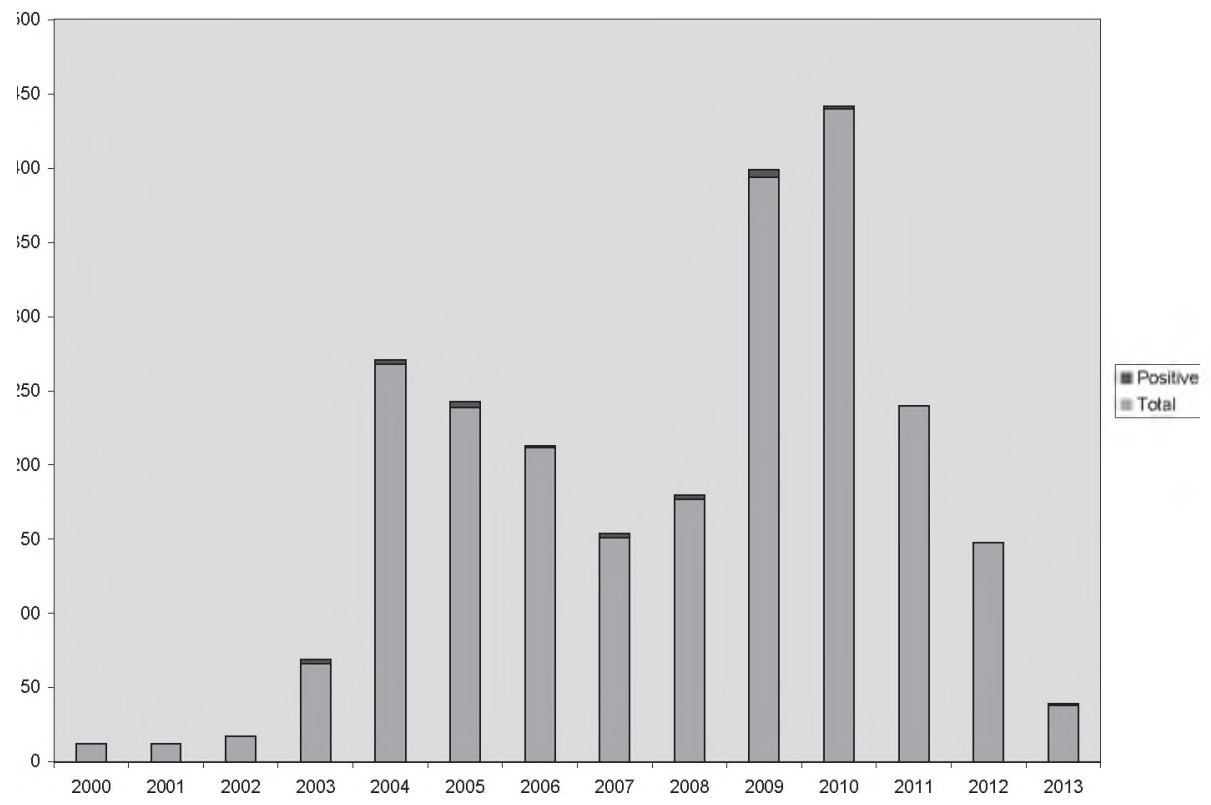

Chart 1. Presence of Anisakis spp. in samples of imported fish.

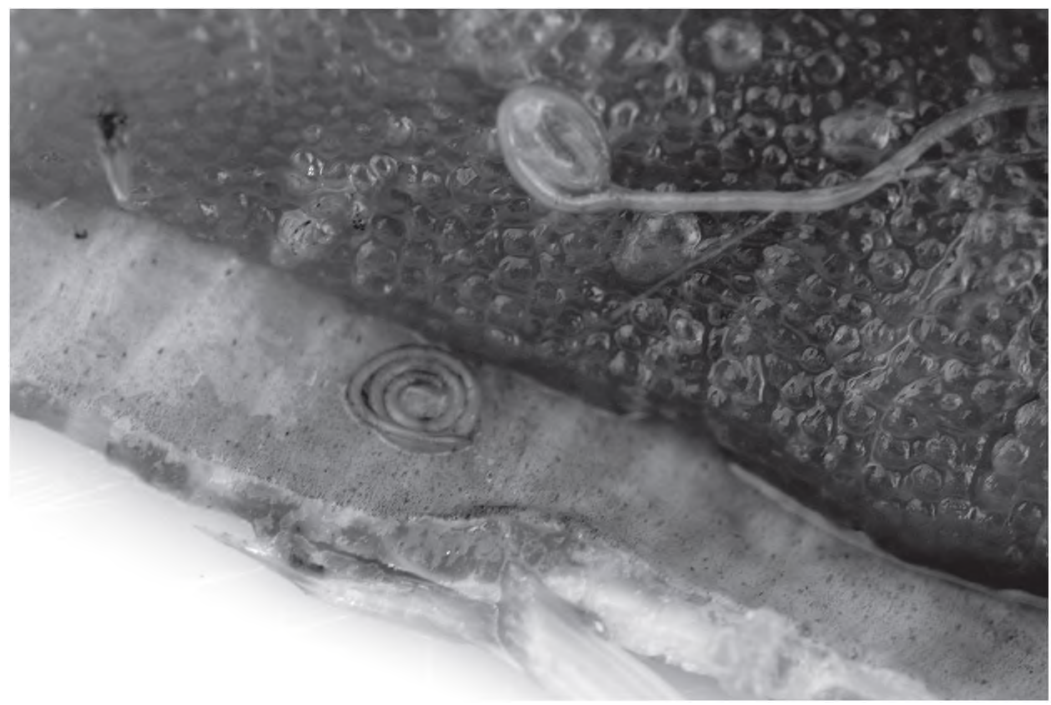

Figure 1. Appearance of Anisakis spp. larvae in herring (Clupea harengus).

Presence of Eustrongylides spp. nematodes was revealed in the abdominal cavity (Figure 2), musculature, in the lumen of the stomach and encapsulated 
in stomach in 4 individuals of zander and 6 individuals of European catfish, what represented the prevalence of $14.26 \%$, respectively $11.54 \%$. During the 2013 at the Institute of veterinary medicine of Novi Sad larvae of Eustrongylides spp. were detected in the muscles of four samples of zander (Fig. 3). The number of parasites per fish ranged from a few up to the 256 . This larva, was robust and pinkish red. Length of body was $27-60.5 \mathrm{~mm}$, maximum width $0.49-0.58 \mathrm{~mm}$.

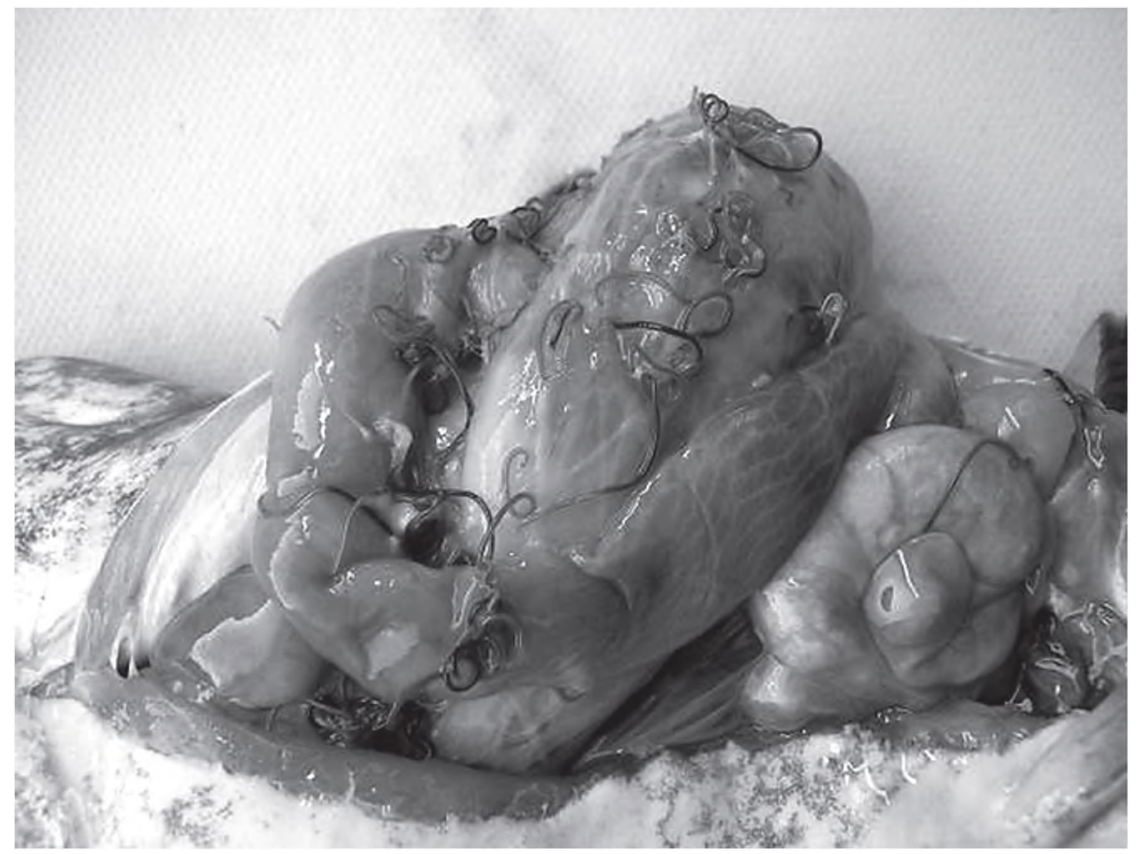

Figure 2. Eusrongylides sp. in the abdominal cavity of European catfish (Siluris glanis). 


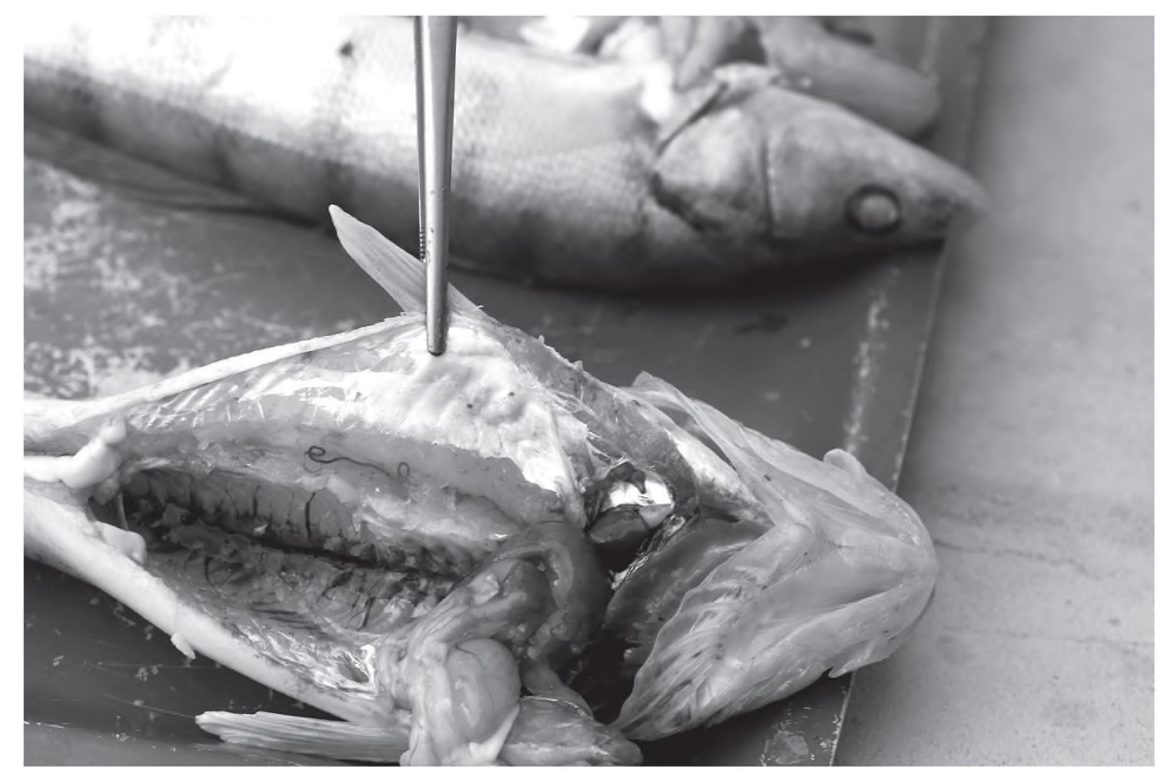

Figure 3. Eusrongylides spp. in the muscles of zander (Sander lucioperca).

Fish parasites such as Anisakis spp. and Eustrongylides spp. are highly important because they are capable to infect humans (Mohammad et al., 2011). Murrell (2002) suggested several control measures for preventing parasitic infections originating from freshwater, such as environmental control of surface water, hygienic aquaculture, and the control or elimination of the first intermediate hosts. FDA (2001) indicated that the effective methods for killing parasites are freezing, heating, adequate combination of salt content and storage time or hot smoking. On the other hand, brining and cold smoking may reduce the parasite hazard in fish, but they do not eliminate or minimize it to an acceptable level (Murrell, 2002). While health education is a key factor in combating zoonotic infections, experience in various countries has shown that for successful implementation of control measures, it is necessary, as Hughes (1992) points out, to have formal and informal cooperation between medical and veterinary interests at all levels of government, and with the community. According to Okumura et al., (1999) and Chieffi et al., (1992), the recommendation to avoid consumption of raw or poorly cooked fish is still the best preventive procedure. 


\section{CONCLUSION}

Zoonotic nematodes can lead to human infection and should pay special attention on them. Fresh fish meat and traditional fish product should be subjected to a visual examination for the purpose of detecting visible nematodes and other parasites before being placed in the trade. The consumption forms and the preparation of the fish food should be modified in a way that hazards to human health due to zoonotic parasites could be avoided. Health education is a key factor in combating zoonotic infections.

\section{LITERATURE}

1. Anderson R. C.: Nematode Parasites of Vertebrates Their Development and Transmission. 2nd Edition. CABI Publising, 2000.

2. Bauer, O. N.: Key for determination of freshwater fish parasites of SSSR. Academy of science SSSR. Lenjingrad. (Ru), 1987.

3. Bullini L.:Antarctic Communities: Species, Structure, and Survival. UK: Cambridge University Press, 1997.

4. Chai Jong-Y., Murell K.D., Lymberyc J.A.: Fish borne parasitic zoonoses: Status and issues, International Journal for Parasitology, 35, 1233-1254., 2005.

5. Chieffi P.P., Gorla M.C.O., Vieira Tores D.M.A.G.: Human infection by Phagicola sp. (Trematoda-Heterophyidae) in the municipality of Registro, São Paulo State, Brazil. Rev. Inst. Med. Trop. São Paulo, 32, 285-288., 1992.

6. Cole R.A.: Eustrongylidosis. In: Field Manual of Wildlife Diseases: General Field Procedures and Diseases of Birds (ed. by M. Friend and J.C. Franson), pp. 223-228. Biological Resources Division, Information and Technology Report 1999- 2001, U. S. Geological Survey, Washington, DC, 1999.

7. Lima dos Santos C.A,M., Howgate P.: Fish born zoonotic parasites and aquaculture: A review, Aquaculture, doi: 10.1016/j.aquaculture. 2011.05.046., 2011.

8. Ljubojević D., Bijelić-Čabrilo O., Novakov N., Cirković M., Davidov I., Jovanović M.: Eustrongylides sp. In freshwater fish species as a potential hazard for humans. Proceedings of the international conference BFSQ, Belgrade, Serbia 2012.

9. Deardorff T.L. and Overstreet R.M.: Seafood-transmitted zoonoses in the United States: the fishes, the dishes, and the worms. In: Microbiology of Marine Food Products (ed. by D.R. Ward \& C.R. Hackney), pp. 211-265. Van Nostrand Reinhold, New York, 1991.

10. FDA,: Fish and Fisheries Products Hazards and Controls Guidance. 3rd Edition. Food and Drug Administration, Center for Food Safety and Appli- 
ed Nutrition, Washington, DC, USA http://www.fda.gov/Food/Guidance Compliance Regulatory Information/Guidance Documents/Seafood/Fish and Fisheries Products Hazards and Controls Guide/default.htm, 2001.

11. Guerin P.F., Marapendi S., MC Grail L.: Intestinal perforation caused by larval Eustrongylides. Morb. Mort. Week. Rep., 31, 383-389., 1982.

12. Hughes K.L.: The impact of zoonotic diseases on the workforce and the community. pp. 301-313 in Zoonoses. Proceedings 194, Post Graduate Committee in Veterinary Science, University of Sydney, 1992.

13. Measures L.N.: Revision of the genus Eustrongylides Ja"gerskio"ld, 1909 (Nematoda: Dioctophymatoidea) of piscivorous birds. Canadian Journal of Zoology 66, 885-895., 1988.

14. Mitchum D.L.: Parasites of Fishes in Wyoming. Wyoming Game and Fish Department, Cheyenne, WY. Overstreet R.M. (2003) Presidential address: flavor buds and other delights. Journal of Parasitology 89, 1093-1107., 1995.

15. Mohammad R., Iraj M., Mahzad A. M., Behyar J., Bagher A. F., Saeed S.S.: Occurrence and intensity rate of internal Metazoan parasites in Rutilus frisii kutum and the first report of Dioctophyma renale (Nematoda: Dioctophymidae) in Iran. World J Zool, 6(1):91-97., 2011.

16. Moravec F.: Parasitic nematodes of freshwater fishes of Europe, Kluwer Academic Publishers, 1994.

17. Murrell K.D.: Fishborne zoonotic parasites: epidemiology of freshwater fishes of Europe, Kluwer Academic Publishers, 1994., detection and elimination. Lactic acid bacteria in fish preservation. In: H.A. Bremner (Ed), Safety and quality issues in fish processing. Woodhead Publishing Ltd. CRC pres, New York: 114-141. 2002.

18. Novakov N., Bjelić-Čabrilo O., Ćirković M., Ljubojević D., Lujić J., Davidov I., Jovanović M.: Eustrongylidosis of European Catfish (Siluris glanis). Bulg. J. Agric.Sci., Supplement 1:72-76., 2013.

19. Okomura M.P.M., Derez A.C.A., Espindola A.: Principais zoonoses parasitárias transmitidas por pescado - revisão. Rev. Ed. Cont., 2, 66-80.(Sp)., 1999.

20. Oliva M.: Matazoan parasites of the jack mackerel Trachurus murphyi in a latitudinal gradient from South America (Chile and Peru). Parasite, 6 (3): 223-230. 1999.

21. Overstreet R.M.: Pesidential address: flavor buds and other delights. Journal of Parasitology 89, 1093-1107., 2003.

22. Roberts L., Janovy J.,undations of Parasitology: Sixth Edition. Boston: McGraw-Hill Higher Education.,, 2000.

23. Spalding M.G. and Forrester D.J., 1993. Pathogenesis of Eustrongylides 
ignotus (Nematode: Dioctophymatoidea) in Ciconiiformes. Journal of Wildlife Diseases 29, 250-260., 1993.

24. Spalding M.G., Bancroft T.B. and Forrester D.J.: The epizootiology of eustrongylidosis in wading birds (Ciconiiformes) in Florida. Journal of Wildlife Diseases 29, 237-249., 1993.

Received / Primljeno: 15.11.2013.

Accepted / Odobreno: 08.12.2013. 